\title{
Uranium distribution in the Variscan Basement of Northeastern Sardinia
}

\section{Kaçeli Xhixha, M. Albèri, M. Baldoncini, G.P. Bezzon, G.P. Buso, I. Callegari,} L. Casini, S. Cuccuru, G. Fiorentini, E. Guastaldi, F. Mantovani, L. Mou, G.

Oggiano, A. Puccini, C. Rossi Alvarez, V. Strati, G. Xhixha \& A. Zanon

To cite this article: M. Kaçeli Xhixha, M. Albèri, M. Baldoncini, G.P. Bezzon, G.P. Buso, I. Callegari, L. Casini, S. Cuccuru, G. Fiorentini, E. Guastaldi, F. Mantovani, L. Mou, G. Oggiano, A. Puccini, C. Rossi Alvarez, V. Strati, G. Xhixha \& A. Zanon (2015): Uranium distribution in the Variscan Basement of Northeastern Sardinia, Journal of Maps, DOI: 10.1080/17445647.2015.1115784

To link to this article: http://dx.doi.org/10.1080/17445647.2015.1115784

+ View supplementary material $\longleftarrow$

曲 Published online: 30 Nov 2015.

Submit your article to this journal ¿

View related articles ־

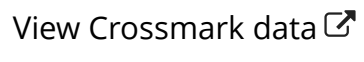




\title{
ORIGINAL ARTICLE
}

\section{Uranium distribution in the Variscan Basement of Northeastern Sardinia}

\author{
M. Kaçeli Xhixha ${ }^{a, b}$, M. Albèric ${ }^{c, e}$, M. Baldoncini ${ }^{b, c, e}$, G.P. Bezzon ${ }^{d}$, G.P. Buso ${ }^{d}$, I. Callegari $^{b, d}$, \\ L. Casinif , S. Cuccuruf, G. Fiorentini ${ }^{c, e}$, E. Guastaldi ${ }^{b, g}$, F. Mantovani ${ }^{c, e}$, L. Mou ${ }^{d}$, G. Oggiano ${ }^{f}$, \\ A. Puccinif, C. Rossi Alvarez ${ }^{d}$, V. Strati ${ }^{b, c, d}$, G. Xhixha ${ }^{b, d}$ and A. Zanon ${ }^{d}$
}

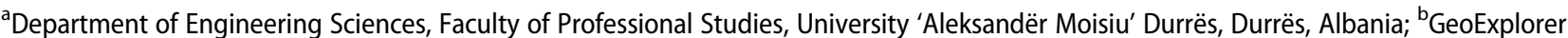
Impresa Sociale S.r.I., Arezzo, Italy; 'Department of Physics and Earth Sciences, University of Ferrara, Ferrara, Italy; ${ }^{\text {' }}$ INFN, Legnaro National Laboratories, Padua, Italy; ${ }^{e}$ INFN, Ferrara Section, Ferrara, Italy; ${ }^{f}$ Nature and Environment Department, University of Sassari, Sassari, Italy;

${ }^{9}$ University of Siena, Center for GeoTechnologies, Arezzo, Italy
\end{abstract}

\begin{abstract}
We present a detailed map of uranium distribution and its uncertainties in the Variscan Basement of Northeastern Sardinia (VBNS) at a scale of 1:100,000. An area of $2100 \mathrm{~km}^{2}$ was investigated by means of 535 data points obtained from laboratory and in situ gamma-ray spectrometry measurements. These data volume corresponds to the highest sampling density of the European Variscides, aimed at studying the genetic processes of the upper crust potentially triggered by an enrichment of radiogenic heat-producing elements. For the first time, the Kriging with Variance of Measurement Error method was used to assign weights to the input data which are based on the degree of confidence associated with the measurements obtained using different gamma-ray spectrometry techniques. A detailed tuning of the model parameters for the adopted Experimental Semi-Variogram led to the identification of a maximum distance of spatial variability coherent to the observed tendency of the experimental data. We demonstrate that the obtained uranium distribution in the VBNS, characterized by several calc-alkaline plutons emplaced within migmatitic massifs and amphibolite-facies metamorphic rocks, is an excellent benchmark for the study of 'hot' collisional chains. The uranium map of VBNS, and in particular the Arzachena minor pluton, confirms the emplacement model based on the recognition of the different petrological associations characterizing the Variscan magmatic processes in the Late Paleozoic. Furthermore, the presented model of the uranium content of the geological bedrock is a potential baseline for future mapping of radon-prone areas.
\end{abstract}

ARTICLE HISTORY

Received 6 August 2015

Revised 7 October 2015

Accepted 30 October 2015

\section{KEYWORDS}

Variscan-Sardinian batholith; in situ and laboratory gamma-ray spectroscopy; Kriging with Variance of Measurements Errors; Arzachena pluton; radiogenic heat-producing elements; Variscan granitoids

\section{Introduction}

The Variscan Basement of Northeastern Sardinia (VBNS) is a benchmark for the study of 'hot' collisional chains characterized by a high temperaturelow pressure (HT-LP) gradient. Several processes might have enhanced the Variscan geotherm, such as (i) shear heating (Casini, Cuccuru, Puccini, Oggiano, \& Rossi, 2015; Maino et al., 2015), (ii) the advection of hot, mantle-derived melts, (iii) the break-off of the mantle lithosphere (Li, Faure, \& Lin, 2014) or (iv) the selective enrichment of radiogenic heat-producing elements, such as $\mathrm{U}, \mathrm{Th}$ and $\mathrm{K}$, in the crust (Lexa et al., 2011). The widespread late-Variscan magmatism in the Corsica-Sardinia Batholith (C-SB) has been occasionally explained in terms of enhanced radiogenic heating. The models that describe the efficiency of the processes depend strongly on the uranium content of the fertile crust (Bea, 2012). The heterogeneous distribution of uranium throughout the VBNS might be a proxy for investigating the applicability of thermal models based on the selective enrichment of radiogenic elements in the crust (Mohamud, Cózar, RodrigoNaharro, \& Pérez del Villar, 2015; Tartèse, Boulvais,
Poujol, \& Vigneresse, 2011). In addition, the outcrops in VBNS are the most accessible intrusive bodies for studying the geoneutrino signal in the Borexino experiment (Borexino Collaboration, 2015), which is particularly sensitive to the $\mathrm{U}$ and $\mathrm{Th}$ contents and distributions in the Variscan continental crust (Coltorti et al., 2011).

Finally, this study has implications related to public health, as recent investigations (Bochicchio et al., 2005) show that the Sardinia region is characterized by high values of radon gas, monitored in 124 dwellings. Since for good bedrock exposure, as in the case of VBNS, the correlation between indoor radon concentrations and uranium content of the underlying rocks increases, the results of this study potentially constitute a baseline for future mapping of radon-prone areas.

In this paper, we present a map of the eU distribution (this notation indicates equivalent uranium, as we assume secular equilibrium in the ${ }^{238} \mathrm{U}$ decay chain) in the VBNS at a scale of 1:100,000 as support for further studies regarding the main geophysical, geochemical and geodynamic features of the continental crust in this region. This study is included in the 
framework of a research project which has already led to the production of the total natural radioactivity map of the Tuscany region (Callegari et al., 2013) and Veneto region (Strati et al., 2015).

The spatial model, together with its uncertainties, was obtained using the Kriging with Variance of Measurement Error method for 535 gamma-ray spectrometry measurements. The eU distribution is discussed in the geodynamic framework proposed by Casini, Cuccuru, Puccini, et al. (2015), taking into account the petrological features of the C-SB, the compositional variation and the emplacement timing of Variscan granitoids. Finally, we focus on the eU distribution measured in the granitoids of the Arzachena pluton, linking it to the emplacement mechanism proposed by Casini, Cuccuru, Maino, Oggiano, and Tiepolo (2012).

\section{Geological setting}

The Variscan belt of Western Europe resulted from the collision of Northern Gondwana and Laurussia in a time interval spanning from the Late Devonian to the Early Permian ( 380-270 Ma). The European Variscan crust, including the Corsica-Sardinia massif, experienced several episodes of plutonic and volcanic activity with different petrochemical affinities (Corsini \& Rolland, 2009; Finger, Roberts, Haunschmid, Schermaier, \& Steyrer, 1997).

The C-SB, with its ca. $12,000 \mathrm{~km}^{2}$ area, constitutes one of the largest batholiths in south-western Europe, emplaced at approximately $40 \mathrm{Ma}$ (Late Mississippian
Pennsylvanian-Early Permian). Three main magmatic suites can be recognized: a magnesium-potassium complex exposed only in northern Corsica, a peraluminous calc-alkaline complex (Casini et al., 2012; Rossi \& Cocherie, 1991) and finally, a late to postorogenic alkaline suite in the VBNS (Bonin, 2007). The $2100 \mathrm{~km}^{2}$ of the VBNS (Figure 1) are characterized by several calc-alkaline plutons and a few minor alkaline complexes emplaced within migmatites and amphibolite-facies of metamorphic rocks (Casini, Cuccuru, Maino, et al., 2015). According to Cruciani, Franceschelli, Massonne, Carosi, and Montomoli (2013), the migmatites outcropping in the study area are related to high-pressure metamorphism that occurred in the Internal Nappes of the Sardinia Variscides at the age of the initial continent-continent collision.

Both migmatites and the calc-alkaline plutons have been interpreted in terms of extensive crustal melting related to the establishment of an anomalous thermal gradient (Anderson, 2006). One of the main contributions to the high geothermal gradient, which is required to induce anatexis processes, originates from the enrichment of radiogenic heat-producing elements caused by several genetic processes, such as subduction of continental crust, crust-scale migmatization ( $\mathrm{Li}$ et al., 2014), melt dehydration and segregation (Gerdes, Worner, \& Henk, 2000). Understanding heat production and transfer mechanisms is relevant for modeling thermalkinematic and exhumation processes (Lexa et al., 2011).

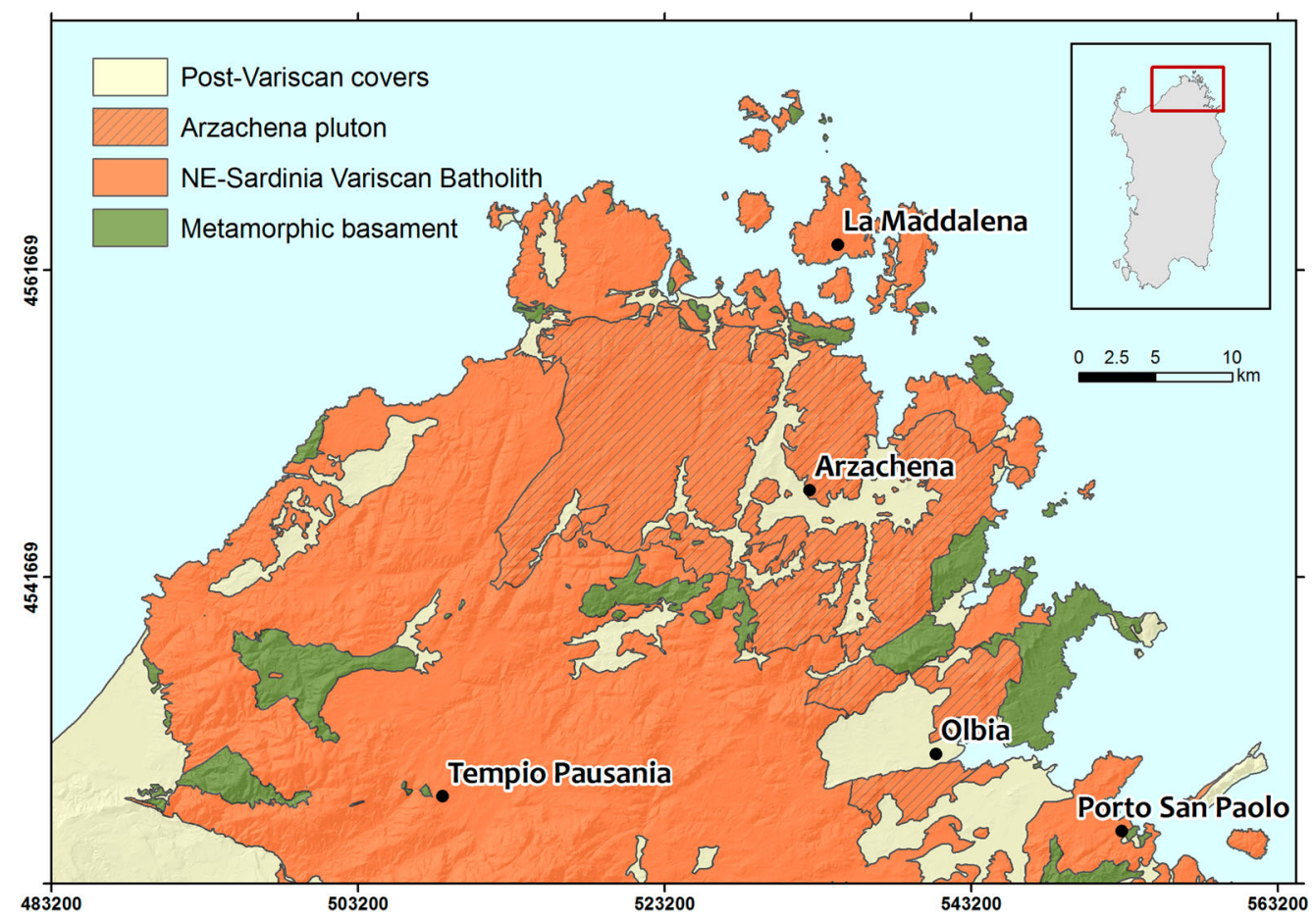

Figure 1. Geological sketch map of the VBSN (cartographic reference system WGS84 UTM ZONE 32N), modified from Casini, Cuccuru, Maino et al. (2015). 
Table 1. Uranium average abundance $U(\mu \mathrm{g} / \mathrm{g})$, standard deviation $\sigma(\mu \mathrm{g} / \mathrm{g})$ and goodness of fit (normalized $x^{2}$ ) obtained with normal and lognormal probability density functions applied to all data and both datasets (i.e. HPGe and $\mathrm{Nal}(\mathrm{TI})$ ).

\begin{tabular}{lcccccc}
\hline & & \multicolumn{2}{c}{$\begin{array}{c}\text { Normal } \\
\text { distribution }\end{array}$} & & \multicolumn{2}{c}{$\begin{array}{c}\text { Lognormal } \\
\text { distribution }\end{array}$} \\
\cline { 3 - 4 } Dataset & Number of records & $U \pm \sigma(\mu \mathrm{g} / \mathrm{g})$ & $\chi^{2}$ & & $U \pm \sigma(\mu \mathrm{g} / \mathrm{g})$ & $x^{2}$ \\
\hline $\mathrm{HpGe}$ & 167 & $3.5 \pm 1.9$ & 1.7 & & $2.9_{-1.5}^{+3.3}$ & 4.3 \\
$\mathrm{Nal}(\mathrm{TI})$ & 368 & $5.2 \pm 2.2$ & 6.0 & & $4.8_{-1.6}^{+2.4}$ & 0.5 \\
All data & 535 & $4.7 \pm 2.3$ & 4.5 & & $4.1_{-1.8}^{+3.3}$ & 6.1 \\
\hline
\end{tabular}

\section{Methods}

The 535 input data points used for producing the Main Map come from 167 rock sample measurements and 368 in situ measurements. The studies were planned based on the Geological map of Sardinia at a scale of 1:200,000 (Barca et al., 1996) and the structural map of Variscan Northern Sardinia at a scale of 1:100,000 (Casini, Cuccuru, Maino, et al., 2015).

The eU abundances in the rock samples collected from fresh outcrops were measured using the MCARad system, a gamma-ray spectrometer equipped with two HPGe p-type detectors having a $60 \%$ relative coaxial efficiency and an energy resolution of approximately $1.9 \mathrm{keV}$ at $1332.5 \mathrm{keV}\left({ }^{60} \mathrm{Co}\right.$ ) (Xhixha et al., 2013). The MCA-Rad system is shielded with a 10 $\mathrm{cm}$ thickness of copper and $10 \mathrm{~cm}$ thickness of lead so reducing the laboratory background by approximately two orders of magnitude. The absolute peak energy efficiency of the MCA-Rad system is calibrated using certified reference materials (RGK_1, RGU_1 and RGTh_1) traceable by the International Atomic Energy Agency (IAEA) (Xhixha et al., 2015). The total uncertainty for the absolute peak energy efficiency is estimated to be less than 5\%. Prior to measurement, each rock sample was crushed, homogenized and sealed in a cylindrical polycarbonate container of $180 \mathrm{~cm}^{3}$ volume. Then, the samples were left undisturbed for at least four weeks to establish radioactive equilibrium in the ${ }^{226} \mathrm{Ra}$ decay chain segment. Each sample was measured for 3600 seconds with a statistical uncertainty generally less than $10 \%$ for eU. Less than $2 \%$ of the measurements are below the minimum detection activity of $\sim 2.5 \mathrm{~Bq} / \mathrm{kg}$.

In this study, a total of 368 in situ gamma-ray measurements were performed on granitic outcrops using a portable $\mathrm{NaI}(\mathrm{Tl})$ detector mounted in a backpack to allow flexible operation (Figure 2), with an acquisition live time of 300 seconds. The $\mathrm{NaI}(\mathrm{Tl})$ detector is of a cubic shape $(10.2 \mathrm{~cm} \times 10.2 \mathrm{~cm} \times 10.2 \mathrm{~cm})$ and has an energy resolution of $7.3 \%$ at $662 \mathrm{keV}$ $\left({ }^{137} \mathrm{Cs}\right)$ and $5.2 \%$ at 1172 and $1332 \mathrm{keV}\left({ }^{60} \mathrm{Co}\right)$. The instrument was calibrated following the method of Full Spectrum Analysis with the Non-Negative Least Squares (FSA-NNLS) constraint, as described in Caciolli et al. (2012). According to the FSA-NNLS method, each spectrum was reconstructed from a linear combination of standard spectra for ${ }^{238} \mathrm{U},{ }^{232} \mathrm{Th}$, ${ }^{40} \mathrm{~K},{ }^{137} \mathrm{Cs}$ and for the background. The uncertainty of the method is estimated to be $5 \%$ for ${ }^{40} \mathrm{~K}$ and $7 \%$ for ${ }^{232} \mathrm{Th}$, with relatively higher uncertainty for ${ }^{238} \mathrm{U}$ of approximately 15\%. In Caciolli et al. (2012), the coefficient of correlation $(0.87 \pm 0.12)$ between the eU values obtained by $\mathrm{NaI}(\mathrm{Tl})$ and $\mathrm{HPGe}$ is compatible with unity at the 1 sigma level. Despite this strong agreement between the two acquisition methods, it is well known (IAEA, 2003) that in situ gamma-ray measurements are susceptible to many sources of 'noise': the geometry of the investigated area, the presence of atmospheric radon, the soil moisture content, the weathering and the outcrop exposure can affect the gamma signal, decreasing the precision of the study.

Because in our study we include the field measurements, relevant precautions were taken to ensure the reliability of our data. Indeed, we avoided acquiring data immediately after rainfall and preferred flat outcrops far from man-made constructions (Figure 2).

In the $U$ decay chain, disequilibrium occurs when one or more isotopes are completely or partially removed or added to the system. Because gamma-ray spectroscopy is a method that detects the gamma emitter daughters of uranium, secular equilibrium of the decay chains is commonly assumed and is reported as the equivalent uranium (eU).
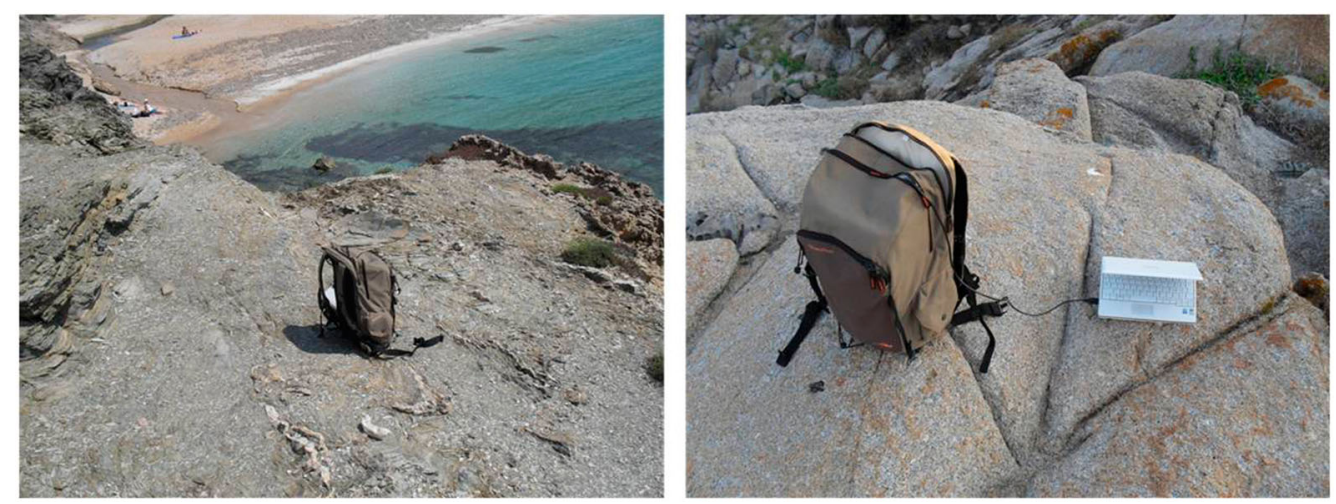

Figure 2. Field measurements using the portable Nal(TI) detector. 


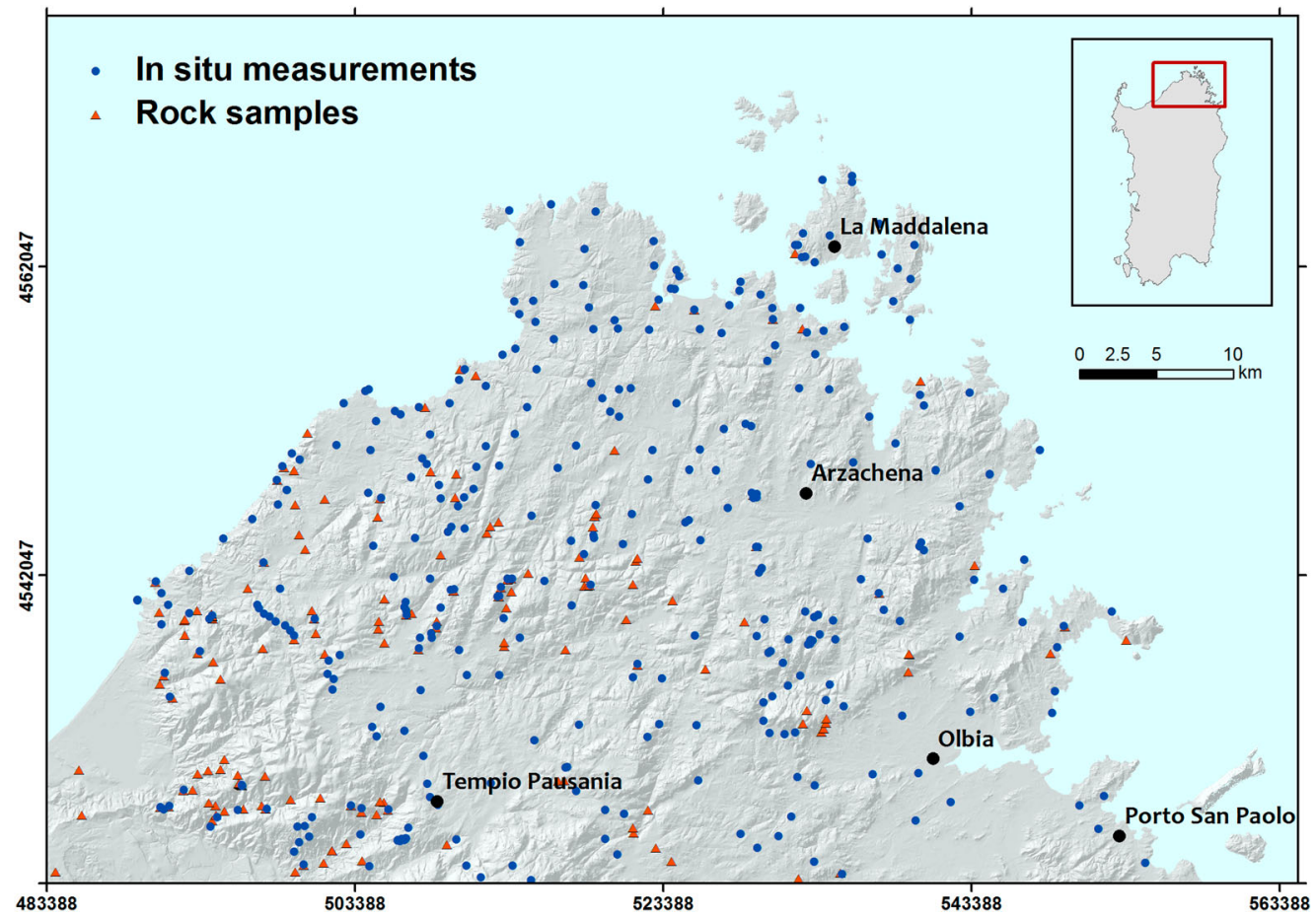

Figure 3. Locations of the 167 collected rock samples and the 368 in situ measurements (cartographic reference system WGS84 UTM ZONE 32N).

\section{Mapping radiometric data}

The map of eU distribution in the VBNS, at a spatial resolution of $100 \mathrm{~m} \times 100 \mathrm{~m}$, was obtained using the Ordinary Kriging with all the 535 measurements acquired by $\mathrm{HPGe}$ and $\mathrm{NaI}(\mathrm{Tl}$ ) (Figure 3 ) using the Kriging method. The frequency distribution and principal statistical parameters of the input data and the output model are reported on the Main Map.

The exploratory statistical analysis highlights that the HPGe and $\mathrm{NaI}(\mathrm{Tl})$ data are characterized by frequency distributions (Figure 4) described by the statistical parameters reported in Table 1. We emphasize that the distributions are affected by a sampling bias

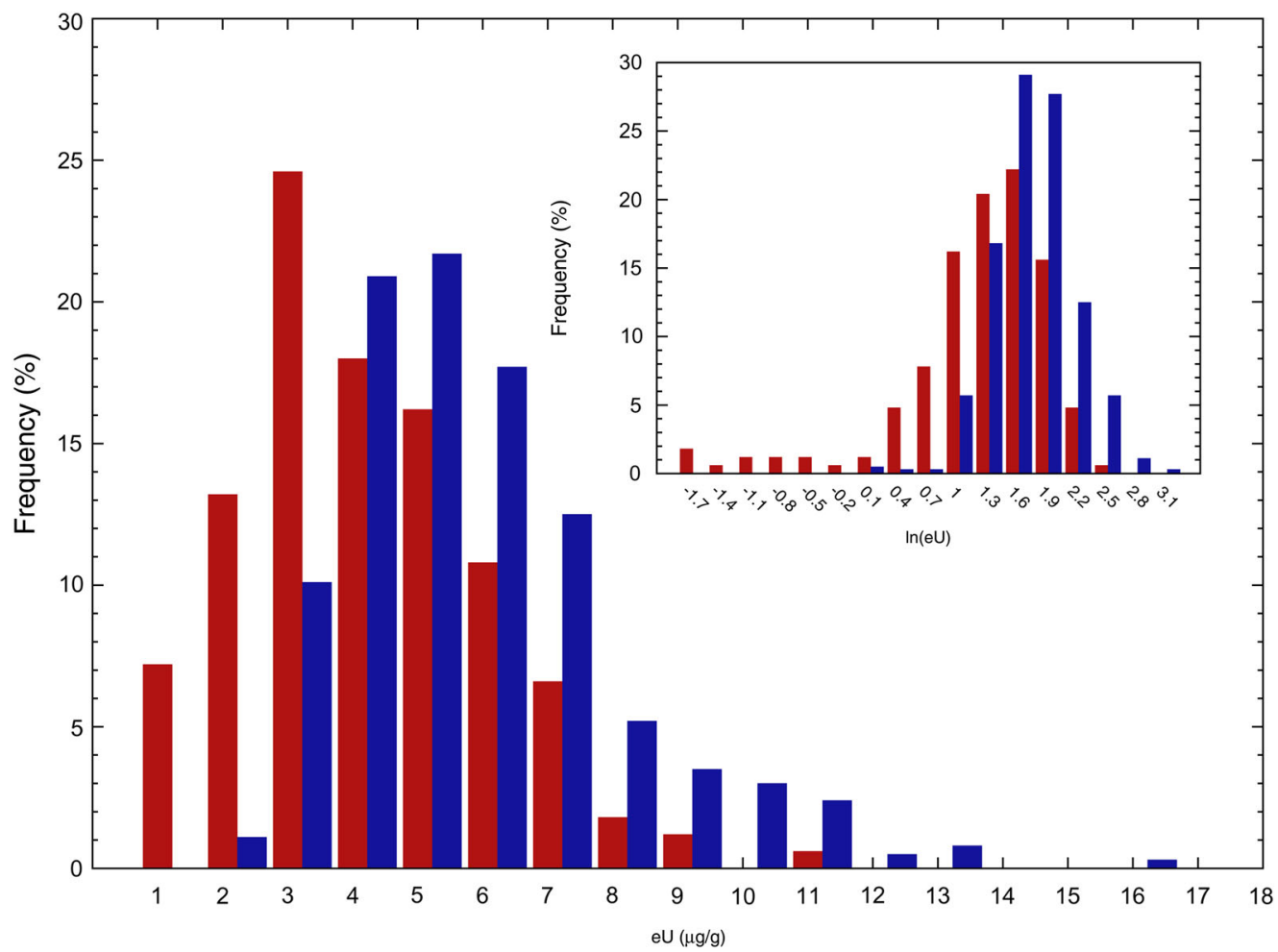

Figure 4. The frequency distributions of the eU abundances $(\mu \mathrm{g} / \mathrm{g})$ in rock samples (red) and in situ measurements (blue). 
Table 2. Parameters of the structures of variability used for the model fitted on the ESV; results of the cross-validation procedure in terms of the Mean of Standardized Errors (MSE) and the Variance of Standardized Errors (VSE).

\begin{tabular}{|c|c|c|c|c|}
\hline \multicolumn{3}{|l|}{ ESV model parameters } & \multicolumn{2}{|c|}{$\begin{array}{l}\text { Cross- } \\
\text { validation } \\
\text { results }\end{array}$} \\
\hline Structures of variability & Range $(\mathrm{km})$ & Sill $(\mu \mathrm{g} / \mathrm{g})^{2}$ & MSE & VSE \\
\hline Nugget effect model & - & 1.7 & & \\
\hline First spherical model & 3.4 & 2.4 & -0.04 & 0.74 \\
\hline Second spherical model & 1.4 & 0.8 & & \\
\hline
\end{tabular}

because each lithology was not investigated using the same number of records in the two datasets: this is particularly clear in observing the tails of the distributions. In fact, the quartzites and amphibolites of the metamorphic basement are characterized by the lowest uranium concentrations $(<2 \mu \mathrm{g} / \mathrm{g})$ and were mainly investigated with HPGe measurements because they are badly exposed and poorly suited to in situ measurements. In contrast, the highest values in Figure 4 are found in the U-rich monzogranites $(\sim 9 \mu \mathrm{g} / \mathrm{g})$ of the La Maddalena pluton (Casini, Cuccuru, Maino, et al., 2015), investigated mostly with in situ studies.

Since the distribution of the input data shows a skewness value close to unity, the study of the spatial variability was performed without any normal transformation of the uranium abundances. A detailed analysis of the directional Experimental Semi-Variograms (ESV) highlighted an isotropic experimental variability without any preferred directions. Therefore, an omnidirectional ESV made up of 9 lags of $2.2 \mathrm{~km}$ was computed and modeled using a trial-and-error procedure (Figure 5). Since we are interested in small-scale variability of $U$ abundances, the parameters used for the ESV modeling were tuned for optimizing the fit in the first lags of the ESV. The nugget effect $\left(1.7 \mu \mathrm{g}^{2} / \mathrm{g}^{2}\right)$, contributing approximately $30 \%$ of the total amount of spatial variability, and the maximum distance of spatial variability equal to $4.8 \mathrm{~km}$ are in excellent agreement with the observed tendency of the experimental data. The goodness-of-fit of the ESV model was checked via a cross-validation procedure. The results are reported in Table 2, together with the parameters of the structures of variability used for the ESV modeling.

The estimation process, performed with Geovariances ISATIS ${ }^{\circ}$ software, takes into account the overall uncertainties of the two methods of gamma-ray measurements as the known Variance of Measurements Error of the input data. In particular, we considered an overall uncertainty of $5 \%$ for each HPGe measurement and a conservative uncertainty of $20 \%$ in the case of the $\mathrm{NaI}(\mathrm{Tl})$ measurements. This methodology, known as Kriging with Variance of Measurement Error, allows for assigning different weights to the input considering the degree of confidence of the measurements, thus improving the quality of the estimations (Deraisme \& Strydom, 2009).

The accuracy of the spatial model in terms of the variance normalized with respect to the estimated values is reported in the Main Map with contour lines. The chromatic variations in the color ramp of

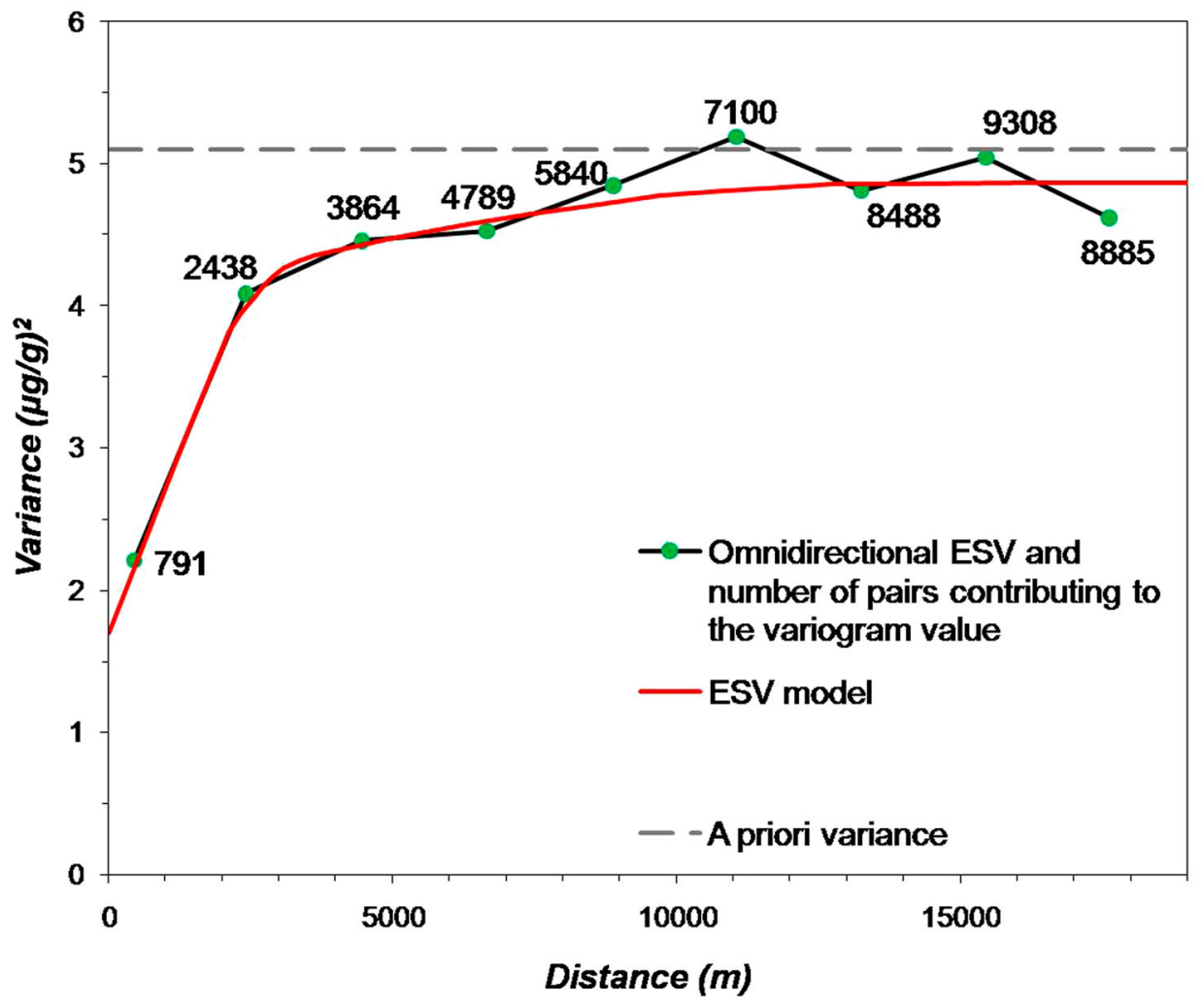

Figure 5. Model fitted for the ESV calculated with 9 lags of $2.2 \mathrm{~km}$. 


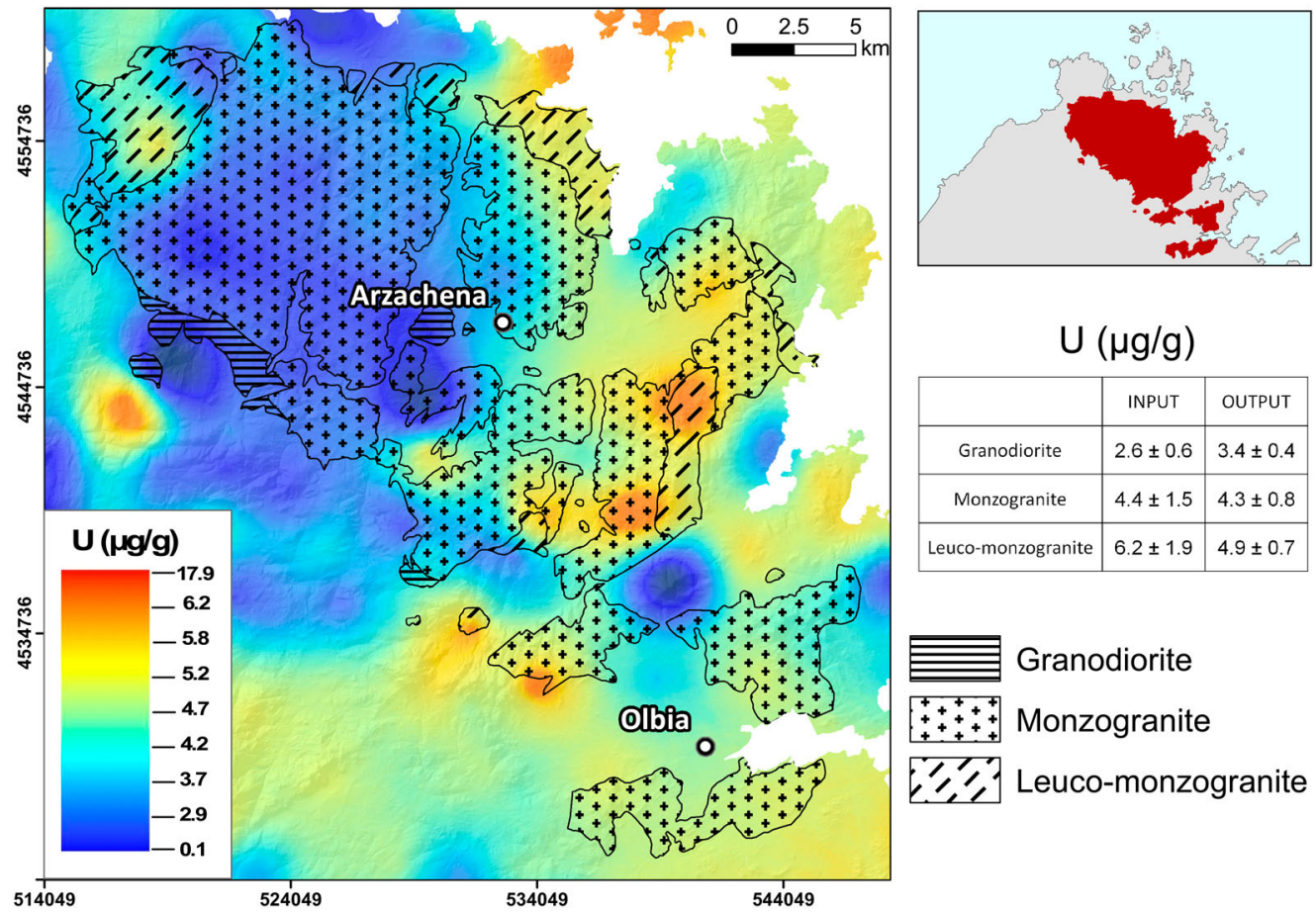

Figure 6. The eU distribution map in the Arzachena pluton with cartographic boundaries of the three different magmatic bodies. The mean and $1 \sigma$ uncertainty of eU abundances of the input data and the output model are reported for each petrological association (cartographic reference system WGS84 UTM ZONE 32N).

the legend were assigned to specific values of eU concentration. In particular, they correspond to the 20th, 35 th, 45th, 55th, 65th, 75th and 80th percentiles calculated for the entire dataset of 535 measurements.

\section{The Arzachena pluton}

In this section, we present a specific focus on the $\mathrm{eU}$ distribution in the Arzachena pluton (AZN), a reference calc-alkaline massif of the VBNS.

The AZN is an elongated pluton that consists of three concentric granitic shells (Oggiano et al., 2005). The pluton shows reverse zonation: the more mafic terms (medium-grained granodiorite) are exposed in the core, along the southern margin of the pluton, whereas the external part is composed of felsic rocks, such as porphyritic biotite-monzogranite and finegrained leuco-monzogranites. This last type of rock represents the more evolved magmatic products and is mainly localized in the peripheral zone of the pluton, exposed to the north (Casini et al., 2012).

In Figure 6, we use the cartographic boundaries of the three granitic shells to distinguish and analyze the range of eU concentrations of the different petrological associations related to the magmatic differentiation during magma emplacement. The mean and $1 \sigma$ uncertainty of the input data and of the spatial model are reported for the three rock types. The granodiorites are characterized by lower eU concentrations (3.4 \pm $0.4 \mu \mathrm{g} / \mathrm{g}$ ). Monzogranites and leuco-monzogranites are enriched in $\mathrm{eU}$ content, with average values of $4.3 \pm 0.8 \mu \mathrm{g} / \mathrm{g}$ and $4.9 \pm 0.7 \mu \mathrm{g} / \mathrm{g}$, respectively. This distribution defines a clear geochemical trend characterized by eU values that increase in felsic rocks. The $\mathrm{eU}$ distribution within the AZN supports a strong positive correlation between the presence of U-bearing accessory minerals (e.g. zircons, monazite and xenotime) and the evolution of magmatic systems (PérezSoba, Villaseca, Orejana, \& Jeffries, 2014). Indeed, melting processes and melt extraction remove a large amount of radioactive elements from the magmatic system that are hosted by accessory minerals in which uranium can substitute other cations with a similar ionic radius and occasionally equal valences (e.g. Ca, trivalent REE, $\mathrm{Zr}$ and $\mathrm{Y}$ ) (Mohamud et al., 2015; Pagel, 1982; Peiffert, Nguyen-Trung, \& Cuney, 1996).

These results confirm the conceptual model proposed in Casini et al. (2012), which explains the distribution of Large-Ion Lithophile Elements (LILE) within AZN in terms of in situ progressive differentiation of anatectic melts sourced from a compositionally heterogeneous lower crust. The obtained $\mathrm{eU}$ distribution in the AZN agrees with the emplacement history and pluton evolution described in the proposed thermo-mechanical model.

\section{Conclusions}

In this study, we present a 1:100,000 scale map of eU abundance distribution in the Variscan Basement, which occupies a total area of $2100 \mathrm{~km}^{2}$ in Northeastern Sardinia. The spatial model was obtained performing Kriging on the 535 gamma-ray measurements and 
is reported together with the uncertainties of the estimations.

Following a detailed statistical analysis performed on the input dataset consisting of 167 laboratory measurements (HPGe) and 368 in situ measurements $(\mathrm{NaI}(\mathrm{Tl}))$, the spatial variability of eU abundance was studied with the computation and modeling of an omnidirectional ESV (9 lags of $2.2 \mathrm{~km}$ ). The map was produced using the Kriging with Variance of Measurement Error method, a geostatistical tool that allows for the combination of eU abundances with different levels of confidence associated with the two different gammaray spectroscopy methods.

The map shows the highest values in the granitoids of the La Maddalena pluton, where the eU content ranges between 6.2 and $9.3 \mu \mathrm{g} / \mathrm{g}$. However, in the metamorphic basement, outcropping in the southwest of the study area (Figure 1), the presence of eclogites intruded in the migmatitic orthogneisses contributes to the lowest uranium abundances $(<2 \mu \mathrm{g} / \mathrm{g})$.

We suggest that the distribution of eU content is related to the Post-Variscan brittle structure, reported in Casini, Cuccuru, Maino, et al. (2015), that affects the metamorphic units and the plutons of the VBNS. In particular, in the Tempio Pausania pluton (southwest of the study area), the major NE-SW faults correspond to anomalies in eU distribution and mark an area with higher $\mathrm{eU}$ content $(5-7 \mu \mathrm{g} / \mathrm{g})$ compared to the adjacent sectors of the pluton with lower eU content $(\sim 3.5 \mu \mathrm{g} / \mathrm{g})$.

In the $\mathrm{AZN}$, the eU content increases in the more differentiated rocks. This behavior can be verified in the spatial model, even if the ranges of the estimated values for granodiorites, monzogranites and leucomonzogranites are affected by the 'smoothing effect' typically associated with the Kriging method.

The presented map, integrated with available and more detailed geological maps, is a useful tool for studying the assembly of the intruded plutons and the relationships between the different petrological associations, based on eU behavior during crustal magmatic processes. Indeed, the study of eU distribution in the VBNS, particularly in the AZN, could help to refine existing models explaining the post-collisional magmatic processes of the southern European Variscides.

We emphasize that about $90 \%$ of the territory of the VBNS is characterized by eU concentrations higher than the average upper continental crust abundance $(2.7 \mu \mathrm{g} / \mathrm{g})$ (Rudnick \& Gao, 2003). Since uraniumrich rocks are generally the main source of radon and the presented distribution is a primary criterion for identifying radon-prone areas. Although radon migration depends on many geophysical parameters (e.g. porosity, fractures and permeability of rocks), the assessment of radon gas emission from the underlying bedrock is strongly recommended for mapping the Radon risk, which could be relevant in coastal areas where the tourism enhances the population density especially in the summer.

\section{Software}

The geostatistical analysis was performed using Geovariances ISATIS . The map was produced using the Esri ArcGIS 9.3.

\section{Acknowledgements}

The authors are extremely grateful to L. Carmignani, T. Colonna, P. Conti and W.F. McDonough who provided insight and expertise that greatly assisted the research. The authors would also like to thank B. Ricci and E. Lisi for comments that considerably improved the manuscript.

\section{Disclosure statement}

No potential conflict of interest was reported by the author (s).

\section{Funding}

This work was partially supported by the Italian Istituto Nazionale di Fisica Nucleare (INFN) through the ITALian RADioactivity project (ITALRAD) and the research grant Theoretical Astroparticle Physics number 2012CPPYP7 under the program PRIN 2012 funded by the Ministero dell'Istruzione, Università e della Ricerca (MIUR).

\section{References}

Anderson, D. L. (2006). Speculations on the nature and cause of mantle heterogeneity. Tectonophysics, 416(1-4), 7-22. doi:10.1016/j.tecto.2005.07.011

Barca, S., Carmignani, L., Oggiano, G., Pertusati, P., Salvatori, I., \& Carmignani, L. (1996). Carta geologica della Sardegna, Servizio Geologico Nazionale. Firenze: Litografia Artistica Cartografica.

Bea, F. (2012). The sources of energy for crustal melting and the geochemistry of heat-producing elements. Lithos, 153, 278-291. doi:10.1016/j.lithos.2012.01.017

Bochicchio, F., Campos-Venuti, G., Piermattei, S., Nuccetelli, C., Risica, S., Tommasino, L., ... Cappai, M. (2005). Annual average and seasonal variations of residential radon concentration for all the Italian regions. Radiation Measurements, 40(2-6), 686-694. doi:10.1016/j.radmeas. 2004.12.023

Bonin, B. (2007). A-type granites and related rocks: Evolution of a concept, problems and prospects. Lithos, 97(1-2), 1-29. doi:10.1016/j.lithos.2006.12.007

Borexino Collaboration. (2015). Spectroscopy of geo-neutrinos from 2056 days of Borexino data. Submitted to Physical Review D. http://arxiv.org/abs/1506.04610

Caciolli, A., Baldoncini, M., Bezzon, G. P., Broggini, C., Buso, G. P., Callegari, I., ... Xhixha, G. (2012). A new FSA approach for in situ $\gamma$ ray spectroscopy. Science of the Total Environment, 414, 639-645. doi:10.1016/j. scitotenv.2011.10.071 
Callegari, I., Bezzon, G. P., Broggini, C., Buso, G. P., Caciolli, A., Carmignani, L., ... Zanon, A. (2013). Total natural radioactivity, Tuscany, Italy. Journal of Maps, 9(3), 438443. doi:10.1080/17445647.2013.802999

Casini, L., Cuccuru, S., Maino, M., Oggiano, G., Puccini, A., \& Rossi, P. (2015). Structural map of Variscan northern Sardinia (Italy). Journal of Maps, 11(1), 75-84. doi:10. 1080/17445647.2014.936914

Casini, L., Cuccuru, S., Maino, M., Oggiano, G., \& Tiepolo, M. (2012). Emplacement of the Arzachena Pluton (Corsica-Sardinia Batholith) and the geodynamics of incoming Pangaea. Tectonophysics, 544-545, 31-49. doi:10.1016/j.tecto.2012.03.028

Casini, L., Cuccuru, S., Puccini, A., Oggiano, G., \& Rossi, P. (2015). Evolution of the Corsica-Sardinia Batholith and late-orogenic shearing of the Variscides. Tectonophysics, 646, 65-78. doi:10.1016/j.tecto.2015.01.017

Coltorti, M., Boraso, R., Mantovani, F., Morsilli, M., Fiorentini, G., Riva, A., ... Chubakov, V. (2011). U and Th content in the central Apennines continental crust: A contribution to the determination of the geo-neutrinos flux at LNGS. Geochimica et Cosmochimica Acta, 75(9), 2271-2294. doi:10.1016/j.gca.2011.01.024

Corsini, M., \& Rolland, Y. (2009). Late evolution of the southern European Variscan belt: Exhumation of the lower crust in a context of oblique convergence. Comptes Rendus Geoscience, 341(2-3), 214-223. doi:10. 1016/j.crte.2008.12.002

Cruciani, G., Franceschelli, M., Massonne, H.-J., Carosi, R., \& Montomoli, C. (2013). Pressure-temperature and deformational evolution of high-pressure metapelites from Variscan NE Sardinia, Italy. Lithos, 175-176, 272284. doi:10.1016/j.lithos.2013.05.001

Deraisme, J., \& Strydom, M. (2009). Estimation of iron ore resources integrating diamond and percussion drillholes. APCOM.

Finger, F., Roberts, M. P., Haunschmid, B., Schermaier, A., \& Steyrer, H. P. (1997). Variscan granitoids of central Europe: Their typology, potential sources and tectonothermal relations. Mineralogy and Petrology, 61(1-4), 67-96. doi:10.1007/BF01172478

Gerdes, A., Worner, G., \& Henk, A. (2000). Post-collisional granite generation and HT-LP metamorphism by radiogenic heating: The Variscan South Bohemian Batholith. Journal of the Geological Society, 157(3), 577-587. doi:10.1144/jgs.157.3.577

IAEA. (2003). Guidelines for radioelement mapping using gamma ray spectrometry data. IAEA-TECDOC1363.

Lexa, O., Schulmann, K., JanoušEk, V., Štípská, P., Guy, A., \& Racek, M. (2011). Heat sources and trigger mechanisms of exhumation of HP granulites in Variscan orogenic root. Journal of Metamorphic Geology, 29(1), 79-102. doi:10. $1111 / j .1525-1314.2010 .00906 . x$

Li, X.-H., Faure, M., \& Lin, W. (2014). From crustal anatexis to mantle melting in the Variscan orogen of Corsica (France): SIMS U-Pb zircon age constraints. Tectonophysics, 634(0), 19-30. doi:10.1016/j.tecto.2014.07.021
Maino, M., Casini, L., Ceriani, A., Decarlis, A., Di Giulio, A., Seno, S., ... Stuart, F. M. (2015). Dating shallow thrusts with zircon $(\mathrm{U}-\mathrm{Th}) / \mathrm{He}$ thermochronometry-the shear heating connection. Geology, 43(6), 495-498. doi:10. 1130/g36492.1

Mohamud, A. H., Cózar, J. S., Rodrigo-Naharro, J., \& Pérez del Villar, L. (2015). Distribution of $U$ and Th in an Iberian U-fertile granitic complex (NW, Spain): Airborne-radiometry, chemical and statistical approaches. Journal of Geochemical Exploration, 148, 40-55. doi:10. 1016/j.gexplo.2014.07.022

Oggiano, G., Cherchi, G., Aversano, A., Di Pisa, A., Ulzega, A., Orrù, P., \& Pintus, C. (2005). Note illustrative della Carta Geologia d'Italia, Foglio 428 Arzachena. S. EL. CA, Firenze.

Pagel, M. (1982). The mineralogy and geochemistry of uranium, thorium, and rare-earth elements in two radioactive granites of the Vosges, France. Mineralogical Magazine, 46(339), 149-161. doi:10.1180/minmag.1982. 046.339 .01

Peiffert, C., Nguyen-Trung, C., \& Cuney, M. (1996). Uranium in granitic magmas: Part 2. Experimental determination of uranium solubility and fluid-melt partition coefficients in the uranium oxide-haplogranite- $\mathrm{H}_{2} \mathrm{O}$ $\mathrm{NaX}(\mathrm{X}=\mathrm{Cl}, \mathrm{F})$ system at $770^{\circ} \mathrm{C}, 2$ kbar. Geochimica et Cosmochimica Acta, 60(9), 1515-1529. doi:10.1016/ 0016-7037(96)00039-7

Pérez-Soba, C., Villaseca, C., Orejana, D., \& Jeffries, T. (2014). Uranium-rich accessory minerals in the peraluminous and perphosphorous Belvís de Monroy pluton (Iberian Variscan belt). Contributions to Mineralogy and Petrology, 167(5). doi:10.1007/s00410-014-1008-4

Rossi, P., \& Cocherie, A. (1991). Genesis of a Variscan batholith: Field, petrological and mineralogical evidence from the Corsica-Sardinia batholith. Tectonophysics, 195(2-4), 319-346. doi:10.1016/0040-1951(91)90219-I

Rudnick, R. L., \& Gao, S. (2003). Composition of the continental crust. In R. L. Rudnick (Ed.), The crust, Vol. 3 treatise on geochemistry (pp. 1-64). Oxford: Elsevier.

Strati, V., Baldoncini, M., Bezzon, G. P., Broggini, C., Buso, G. P., Caciolli, A., ... Zanon, A. (2015). Total natural radioactivity, Veneto (Italy). Journal of Maps, 11(4), 545-551. doi:10.1080/17445647.2014.923348

Tartèse, R., Boulvais, P., Poujol, M., \& Vigneresse, J.-L. (2011). Granite petrogenesis revealed by combined gravimetric and radiometric imaging. Tectonophysics, 501(14), 98-103. doi:10.1016/j.tecto.2011.02.003

Xhixha, G., Alberi, M., Baldoncini, M., Bode, K., Bylyku, E., Cfarku, F., ... Kaçeli, M. X. (2015). Calibration of HPGe detectors using certified reference materials of natural origin. Journal of Radioanalytical and Nuclear Chemistry. doi:10.1007/s10967-015-4360-6

Xhixha, G., Bezzon, G. P., Broggini, C., Buso, G. P., Caciolli, A., Callegari, I., ... Shyti, M. (2013). The worldwide NORM production and a fully automated gamma-ray spectrometer for their characterization. Journal of Radioanalytical and Nuclear Chemistry, 295(1), 445-457. doi:10.1007/s10967-012-1791-1 


\section{URANIUM DISTRIBUTION IN THE VARISCAN BASEMENT OF NORTHEASTERN SARDINIA}

Kaçeli Xhixha M.a,b, Albèri M. c,e, Baldoncini M. b,c,e, Bezzon G.P. d, Buso G.P. d, Callegari I. b,d, Casini L.f, Cuccuru S.f, Fiorentini G. . $^{\mathrm{c}, \text {, }}$

Guastaldi E.b,g, Mantovani F.,e, Mou L. ${ }^{\mathrm{d}}$, Oggiano G. f, Puccini A. ${ }^{\mathrm{f}}$, Rossi Alvarez C. ${ }^{\mathrm{d}}$, Strati V. b,c,d, Xhixha G. b,d, Zanon A.

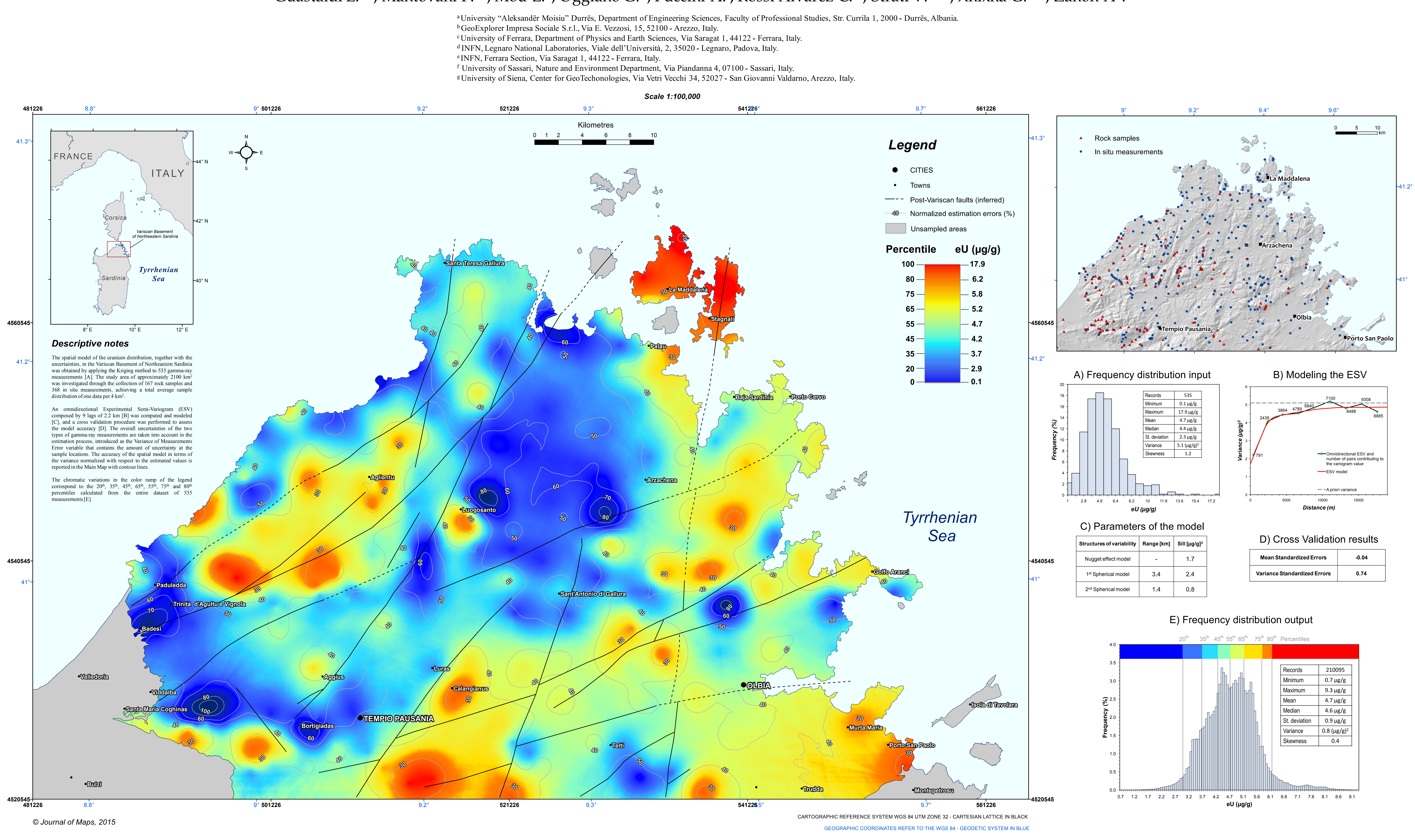

